\title{
Strategi Kepala Madrasah Dalam Mewujudkan Madrasah Unggulan Di MIN 3 Simpang Tiga Kecamatan Bukit Raya Kota Pekanbaru
}

\author{
M. YUSUF AHMAD* \\ DEVI ARISANTI** \\ RIDOAN NASUTION***
}

* Fakultas Agama Islam (FAI) Universitas Islam Riau (UIR) Pekanbaru

Jl. Kaharuddin Nasution, No. 113, Perhentian Marpoyan Pekanbaru 28284. Hp. 081365542760 m.yusuf_ahmad@fis.uir.ac.id

** Fakultas Tarbiyah dan Keguruan Universitas Islam Negeri (UIN) Sultan Syarif Kasim Riau Jl. Kaharuddin Nasution No. 113 Perhentian Marpoyan Pekanbaru 28284 e-mail:deviarisanty@gmail.com

***Fakultas Agama Islam (FAI) Universitas Islam Riau (UIR) Pekanbaru Jl. Kaharuddin Nasution, No. 113, Perhentian Marpoyan Pekanbaru 28284

\begin{abstract}
Abstrak: Kepala Madrasah memiliki peran yang kuat dalam mengkoordinasikan, menggerakkan dan menyerasikan semua sumber daya pendidikan yang tersedia di Madrasah. Kepala madrasah dikatakan sebagai pemimpin yang efektif bilamana kepala sekolah mampu menjalankan proses kepemimpinannya yang mendorong, mempengaruhi dan mengarahkan kegiatan dan tingkah laku kelompoknya. Inisiatif dan kreatifitas kepala madrasah yang mengarah kepada kemajuan madrasah. Berdasarkan fenomena yang terjadi di lapangan, beberapa penyebab sekolah dasar menjadi tidak bermutu antara lain: karena tidak ada standar input (siswa) sehingga kemampuan dan karakteristk siswa sangat beragam, sistem guru kelas berdampak pada menurunnya kinerja guru, kurikulum pada beberapa mata pelajaran masih dianggap terlalu luas, sehingga memberatkan bagi siswa untuk mempelajarinya dan masih adanya guru yang kurang aktif dalam pembelajaran. Penelitian ini bertujuan untuk mengetahui strategi Kepala Madrasah dalam mewujudkan Madrasah Unggulan di MIN 3 Simpang Tiga Kecamatan Bukit Raya Kota Pekanbaru. Tempat penelitian ini di MIN 3 Simpang Tiga Kecamatan Bukit Raya Kota Pekanbaru. Populasi dalam penelitian ini adalah satu orang kepala sekolah. Subjek penelitian ini adalah Kepala MIN 3 Simpang Tiga Kecamatan Bukit Raya Kota Pekanbaru. Pengumpulan data dilakukan dengan pengumpulan informasi, melalui wawancara maupun observasi langsung. Setelah dilaksanakan penelitian dan data yang terkumpul dan dianalisa, strategi yang dibuat oleh kepala sekolah yaitu, peningkatan kemampuan mengajar guru, optimalisasi penggunaan media dan sarana pendidikan, pelaksanaan suvervisi secara rutin, menjalin kerjasama dengan masyarakat dan penerapan disiplin yang ketat yang senatiasa dilaksanakan.
\end{abstract}

Kata kunci: Strategi, Kepala Madrasah, Madrasah Unggulan. 


\section{PENDAHULUAN}

Berbagai upaya telah dilakukan pemerintah untuk meningkatkan pemerataan kualitas sumber daya manusia melalui pendidikan, yaitu diantaranya dengan pengadaan sarana dan prasarana pendidikan, pengadaan tenaga guru kontrak, penataran, penyempurnaan kurikulum dan sebagainya. Permasalahan yang mendasar sebenarnya yaitu mampu atau tidaknya sumber daya pendidikan yang ada atau belum adanya pengelolaan yang efektif dan efisien oleh setiap lembaga penyelenggara pendidikan itu sendiri.

Oleh karena itu, suatu terobosan dalam mewujudkan tujuan pendidikan adalah dengan cara meningkatkan fungsi dan peran kepala madrasah untuk menciptakan sekolah sebagai lingkungan pendidikan yang dapat menghasilkan lulusan dengan beragam tingkat pengetahuan, kemampuan serta nilai atau sikap yang memungkinkan untuk menjadi warga masyarakat dan warga Negara yang bertaqwa terhadap Tuhan yang Maha Esa, beriman dan berbudi pekerti luhur (Dani, 2007: 205).

Kepala Madrasah memiliki peran yang kuat dalam mengkoordinasikan menggerakkan dan menyerasikan semua sumber daya pendidikan yang tersedia di Madrasah. Kepemimpinan kepala Madrasah merupakan salah satu faktor yang dapat mendorong madrasah untuk dapat mewujudkan visi, misi, tujuan dan sasaran madrasah melalui program-program yang dilaksanakan secara terencana dan bertahap (Mulyasa, 2009 : 102).

Kepala Madrasah dikatakan sebagai pemimpin yang efektif bilamana ia mampu menjalankan proses kepemimpinannya yang mendorong, mempengaruhi dan mengarahkan kegiatan dan tingkah laku kelompoknya. Inisiatif dan kreatifitas 137

Vol. 14, No. 2, Oktober 2017 ISSN 1412-5382 kepala madrasah yang mengarah kepada kemajuan madrasah merupakan bagian integrative dari tugas dan tanggung jawab. Fungsi utamanya ialah menciptakan kegiatan belajar mengajar yang efektif dan efisien (Wahyosumidjo, $2001: 3)$

Dalam melaksanakan fungsi tersebut, kepala madrasah memiliki tanggung jawab ganda, yaitu: pertama, melaksanakan administrasi madrasah sehingga dapat tercipta situasi belajar mengajar yang baik. Kedua, melaksanakan suvervisi pendidikan sehingga diperoleh peningkatan kegiatan mengajar guru dalam membimbing murid-murid (Kemendikbud, 2014:34).

Tugas dan tanggung jawab yang harus diemban oleh kepala sekolah dalam memimpin dan mengelola sekolah yaitu meningkatkan mutu pendidikan, artinya bahwa seorang kepala sekolah dituntut untuk mampu mengelola seluruh sumber daya pendidikan yang ada di sekolah, sehingga mampu mendukung terhadap perwujudan tujuan pendidikan yang akan dicapai (Kunandar, 2009:109).

Keadaan tersebut sebagaimana diungkapkan dalam konsep Total Quality Manajemen bahwa mutu suatu produk ditentukan oleh pengelolaan input, proses sampai dengan output. Dengan kata lain bahwa mutu suatu produk akan bagus apabila bahan dasarnya diproses dengan benar dan di kontrol dengan tepat. Demikian pula hal nya dalam pengelolaan lembaga pendidikan, termasuk sekolah dasar. Sementara pada pendidikan dasar, khususnya sekolah dasar di Indonesia, siswa yang masuk (input) tidak diseleksi secara khusus, asal memenuhi persyaratan administrasi mereka bisa diterima (Nurkolis, 2005:154).

Hal senada diungkapkan oleh Bafadhal (2003: 29), bahwasannya untuk mencapai Madrasah yang Jurnal Al-hikmah 
unggulan dituntut adanya tenaga, fasilitas, dan dana yang memadai, dan tidak semua sekolah/ madrasah dapat memenuhinya. Secara teknis, pengembangan Madrasah Unggulan menuntut adanya tenaga yang profesional dan fasilitas yang memadai.

Selain itu, dalam membuat sekolah unggulan dikembangkan pula kelas unggulan, yaitu sejumlah siswa, yang karena prestasinya menonjol, dikelompokkan ke kelas tertentu. Pengelompokan ini dimaksudkan untuk membina siswa dalam mengembangkan kecerdasan, kemampuan, keterampilan, dan potensinya seoptimal mungkin, sehingga memiliki pengetahuan, keterampilan, dan sikap yang terbaik (Bafadal, 2003: 28).

Konsekuensinya dibutuhkan biaya yang tidak sedikit untuk pengembangannya, sehingga uang gedung, SPP juga menjadi mahal yang hanya mampu dipenuhi oleh orangorang kaya, dan kecil sekali kemungkinan bagi orang yang tidak mampu untuk menyekolahkan anaknya ke sekolah unggulan.

Terlebih lagi, ada beberapa permasalahan-permasalahan yang terjadi di lapangan yang merupakan kendala sekolah dasar sehingga menjadikannya tidak bermutu antara lain: karena tidak ada standar input (siswa) sehingga kemampuan dan karakteristk siswa sangat beragam, sistem guru kelas berdampak pada menurunnya kinerja guru, kurikulum pada beberapa mata pelajaran masih dianggap terlalu luas sehinnga memberatkan bagi siswa untuk mempelajarinya dan masih adanya guru yang kurang aktif dalam pembelajaran. Permasalahan-permasalahan tersebut tentunya merupakan suatu kendala bagi dunia pendidikan di sekolah dasar yang keberadaannya perlu segera ditangani benar-benar, sehingga tidak mengganggu atau menghambat terwujudnya tujuan pendidikan yang akan dicapai.

Guna menjawab kesenjangan tersebut, maka melalui pelaksanaan strategi kepala madrasah diharapkan dapat mewujudkan madrasah unggulan. Untuk itu peneliti menyadari betapa pentingnya strategi kepala madrasah dalam mewujudkan madrasah unggulan. Berdasarkan pengamatan awal (studi pendahulu) penulis menemukan gejala-gejala sebagai berikut: (1) Kepala sekolah sudah menjalankan tugas tapi belum sepenuhnya berjalan sesuai dengan harapan dalam mewujudkan madrasah unggulan; dan (2) Masih terlihat kurangnya sebahagian strategi yang digunakan kepala sekolah untuk meningkatkan kinerja guru di MIN 3 Simpang Tiga Kecamatan Bukit Raya Kota Pekanbaru.

Berdasarkan dari gejala-gejala yang dikemukakan di atas, maka penulis tertarik untuk melakukan penelitian dengan judul "Strategi Kepala Madrasah dalam Mewujudkan Madrasah Unggulan di MIN 3 Simpang Tiga Kecamatan Bukit Raya Kota Pekanbaru".

Mengingat banyaknya masalah yang timbul dalam penelitian ini, maka penulis membatasinya pada hal-hal yang menyangkut masalah "Strategi Kepala Madrasah dalam Mewujudkan Madrasah Unggulan di MIN 3 Simpang Tiga Kecamatan Bukit Raya Kota Pekanbaru". Adapun rumusan masalah peneliitian ini adalah sebagai berikut "Bagaimana strategi Kepala Madrasah dalam Mewujudkan Madrasah Unggulan di MIN 3 Simpang Tiga Kecamatan Bukit Raya Kota Pekanbaru?". Sesuai dengan rumusan masalah di atas, maka tujuan penelitian ini adalah: untuk mengetahui strategi Kepala Madrasah dalam mewujudkan Madrasah Unggulan di MIN 3 Simpang 
Tiga Kecamatan Bukit Raya Kota Pekanbaru.

Manfaat penelitian adalah: (1)

Bagi Kepala Madrasah pada umumnya dalam melaksanakan tugas utamanya yang berkaitan dengan strategi mewujudkan Madrasah Unggulan; (2) Bagi guru pada umumnya untuk senantiasa menyadari akan pentingnya peningkatan profesionalisme dalam melaksanakan tugas kegiatan belajar mengajar; (3) Bagi peneliti yang akan dating untuk menambah wawasan tentang Strategi Kepala Madrasah dalam mewujudkan Madrasah Unggulan; dan (3) Untuk sumbangan pemikiran terhadap kemajuan pendidikan di MIN 3 Simpang Tiga Kecamatan Bukit Raya Kota Pekanbaru.

\section{KONSEP TEORI}

\section{Strategi Kepala Madrasah}

Winardi mengemukakan bahwa strategi sebuah organisasi atau subnya merupakan konseptualisasi yang dinyatakan dan akan diimplikasikan oleh pemimpin organisasi yang bersangkutan, meliputi: sasaransasaran jangka panjang atau tujuantujuan organisasi tersebut, kendalakendala luas dan kebijakan-kebijakan yang atau ditetapkan sendiri oleh sang pemimpin, atau yang diterimanya dari pihak atasannya yang membatasi skop aktifitas-aktifitas organisasi yang bersangkutan dan kelompok rencanarencana dan tujuan-tujuan jangka pendek yang telah diterapkan dengan eksperesi akan diberikannya sumbangsih mereka dalam hal mencapai sasaran-sasaran organisasi tersebut (Rahman, 2006:106).

Sementara Salusu mengemukakan bahwa strategi adalah suatu seni menggunakan kecakapan dan nara sumber daya suatu organisasi untuk mencapai sasarannya melalui hubungan yang efektif dengan lingkungan dalam 139

Vol. 14, No. 2, Oktober 2017 ISSN 1412-5382 kondisi yang paling menguntungkan. Konsep tersebut mengemukakan bahwa strategi lebih menekankan pengertiannya pada suatu situasi diman apemimpin mampu mendayagunakan segenap sumber daya organisasi dengan tepat dan benar (Rahman, 2006:119).

Dalam hal ini, maka seorang pimpinan harus dituntut memiliki kepandaian dalam menguasai situasi dan kondisi yang dimiliki oleh organisasi, sehingga mampu menerapkan suatu pengembangan program dan menggerakkan sumber daya organisasi yang dimilikinya. Lebih lanjut Winardi mengemukakan bahwa strategi merupakan pola sasaran, tujuan, atau maksud dan kebijakan utama serta rencana untuk mencaai tujuan tersebut. Konsep tersebut lebih menitikberatkan pada upaya pimpinan dalam menetapkan sasaran yang harus dicapai organisasi melalui suatu perencanaan yang akurat, matang dan sistematis (Wahjosumidjo, 2002:32).

Berdasarkan konsep tersebut, maka strategi merupakan suatu kesatuan rencana yang menyeluruh, komprehensif dan terpadu yang diarahkan untuk mencapai tujuan. Dengan demikian dapat disimpulkan bahwa strategi kepala mdrasah merupakan rangkaian dari rencana sebagai sasaran, kebijakan atau tujuan yang ditetapkan oleh seorang kepala sekolah dalam pembelajaran sesuai dengan kondisi yang ada, sehingga mampu mewujudkan peningkata mutu pembelajaran (Wahjosumidjo, 2002: 34).

Berikut adalah beberapa strategi yang dilakuakan oleh kepala sekolah dalam menciptakan madrasah unggulan: Pertama, Peningkatan Kemampuan Mengajar Guru. Strategi pertama yang diterapkan oleh Kepala Sekolah dalam meningkatkan mutu pembelajaran yaitu dengan cara Jurnal Al-hikmah 
peningkatan kemampuan mengajar guru. Peningkatan kemampuan mengajar ini dipantau oleh Kepala Sekolah sangat penting mengingat gurulah sebagai peran kunci yang melaksanakan dan menentukan baik tidaknya mutu pembelajaran tersebut. Selain itu pula sejumlah permasalahan dalam meningkatkan mutu pembelajaran banyak bersumber dari guru, misalnya kurang disiplin, kurang professional, kinerjanya rendah atau permasalahan-permasalahan pribadi lainnya (Rahman, 2006:45).

Peningkatan kemampuan guru dalam hal ini yaitu meningkatkan kemampuan para guru dalam menjalankan tugas dan kewajibannya sebagai pengajar. Tentunya peningkatan kemampuan ini diharapkan mampu meningkatkan kemampuan guru dalam merencanakan, melaksanakan dan bahkan menilai hasil pembelajaran yang dilakukannya. Pengembangan kemampuan guru yang diterapkan kepala sekolah yaitu dengan cara mengikutsertakan para guru dalam seminar, diklat dan penataran kependidikan yang diselenggarakan oleh lembaga-lembaga keprofesian.

Kedua, Optimalisasi Penggunaan Media dan Sarana Pendidikan. Strategi yang diterapkan kepala sekolah dalam meningkatkan mutu pembelajaran yaitu dengan optimalisasi pemanfaatan dan penggunaan media dan sarana pendidikan. Permasalahan yang muncul dalam hal ini bahwa selama ini guru kurang mendaya gunakan penggunaan media dan sarana pendidikan yang ada, sehingga keberadaannya jelas tidak bermanfaat untuk memperlancar pembelajaran. Optimalisasi penggunaan media dan sarana ini dilakukan dengan cara membuat kebijakan untuk mewajibkan setiap guru dalam melakukan pembelajarannya dengan menggunakan media atau sarana pendidikan yang tersedia, sehingga mampu mewujudkan hasil pengajaran yang optimal.

Untuk memberdayakan penggunaan media dan sarana pendidikan ini pula, Kepala Sekolah berupaya menerapkan pengelolaan yang baik. Kepala Sekolah mendesain atau mengatur penempatan, penggunaan dan pemeliharan dari media dan sarana pendidikan yang ada. Keadaan ini dilakukan dalam upaya mengkondisikan media dan sarana pendidikan yang ada mampu dilindungi dan mampu untuk dimanfaatkan keberadaannya. Lebih lanjut Kepala Sekolah menganggarkan biaya untuk pemeliharaan dan pengadaan media dan sarana pendidikan yang belum tersedia (Rahman, 2006:78).

Ketiga, Pelaksanaan Suvervisi secara Rutin. Strategi yang lain yang diterapkan Kepala Sekolah dalam meningkatkan mutu pendidikan yaitu dengan pelaksanaan suvervisi rutin. Strategi ini pun ditempuh Kepala Sekolah untuk mengatasi permasalahan sehubungan dengan kurangnya sikap profesionalisme yang dilakukan oleh guru dalam melaksanankan tugas (Rahman, 2006:78).

Kegiatan supervisi dilakukan Kepala Sekolah agar Kepala Sekolah mengetahui secara langsung permasalahan yang dihadapi guru selama melaksanakan pembelajaran, sehingga Kepala Sekolah dapat memberikan bantuan sesuai dengan kemampuannya.

\section{Keempat, Menjalin Kerjasama} dengan Masyarakat. Masyarakat merupakan relasi yang cukup besar dalam memberikan pengaruh dan bantuan terhadap kelancaran penyelenggaraan pembelajaran. Apalagi jika dikaitkan dengan keadaan sekarang bahwa masyarakat memiliki peran sebagai pengawas dan penyumbang kebutuhan sekolah dengan dibentuknya "Dewan Sekolah". Namun demikian 
dalam kenyataannya bahwa masyarakat masih kurang peka terhadap kebutuhan sekolah.

Oleh karena itulah sebagai langkah awal memperbaiki hubungan sekolah dengan masyarakat, maka Kepala Sekolah mengadakan suatu strategi dalam bentuk kerjasama dengan masyarakat. Dengan mengadakan hubungan kerjasama dengan masyarakat ini, maka sekolah membentuk Dewan Sekolah yang memiliki fungsi dan peran sebagai wadah untuk memfasilitasi masyarakat berhubungan dengan sekolah atau sebaliknya.

Rapat Dewan Sekolah merupakan upaya menjalin kerjasama dengan masyarakat dalam membahas programprogram pendidikan yang akan diselenggarakan oleh pihak sekolah. Pada pertemuan ini dibahas mengenai program-program yang akan dilaksanakan oleh pihak sekolah.

Kelima, Penerapan Disiplin yang Ketat. Penerapan disiplin yang ketat merupakan salah satu strategi yang dilakukan Kepala Sekolah dalam meningkatkan mutu pembelajaran. Penerapan disiplin ini penting dilakukan sehubungan dengan rendahnya tingkat kedisiplinan guru maupun siswa, antara lain: datang terlambat, berpakaian kurang rapi dan pulang belajar mengajar belum pada waktunya. Pendisiplinan ini dilakukan untuk mengkondisikan semua warga SD memiliki kinerja dalam menjalankan tugas dan perananya secara optimal (Juliana, 2000:23).

Pendisiplinan ini ditegakkan secara objektif, sehingga mampu memberikan kontribusi terhadap peningkatan mutu pembelajaran. Kepala Sekolah setiap hari mengontrol kedisiplinan guru dan siswa dengan cara melihat kehadiran, kerapian dari pakaiannya dan menampilkan prilaku kepemimpinan yang patut untuk 141

Vol. 14, No. 2, Oktober 2017 ISSN 1412-5382 dicontoh atau ditiru. Lebih konkritnya jika ada guru maupun siswa yang tidak berdisiplin, maka Kepala Sekolah melakukan teguran secara lisan, melakukan pemanggilan dan pemberian sanksi apabila guru maupun siswa tetap membandel.

Selain itu pula khusus untuk siswa jika ada yang tidak disiplin, Kepala Sekolah memanggil orang tua siswa ke ssekolah untuk meminta bantuan dalam membina anaknya. Secara lebih kongkrit pendisiplinan yang dilakukan kepada guru, Kepala Sekolah melakukan evaluasi terhadap ketepatan waktu mengajar, kehadiran dan kerapian pakaiannya. Kepala Sekolah terbiasa memanggil guru yang terlambat dalam mengajar, tidak rapi dalam berpakaian dan sering tidak hadir (Juliana, 2000:34).

Kondisi tersebut ditindak lanjuti dengan pembinaan dan pengajaran, sehingga para guru tetap mampu menegakkan kedisiplinannya. Kepala Sekolah menganggap bahwa melalui pendisiplinan inilah nantinya akan mampu memberikan dampak terhadap hasil belajar. Dengan demikian kedisiplinan ini perlu diciptakan dengan baik, sehingga mampu memberikan kontribusi terhadap mutu pembelajaran dengan baik pula.

\section{Konsep Kepala Madrasah}

Kepala madrasah merupakan salah satu komponen pendidikan yang paling berperan dalam meningkatkan kualitas pendidikan. Sebagaimana diungkapkan dalam pasal 12 ayat 1 tahun 1990 bahwa: "Kepala madrasah bertanggung jawab atas penyelenggaran pendidikan, administrasi sekolah, pembinaan tenaga kependidikan lainnya, dan pendayagunaan serta pemeliharaan sarana dan prasarana" (Arikuto, 1990:196). 
Kepala madrasah merupakan orang terpenting di suatu sekolah. Dan penelitian-penelitian maupun pengamatan tidak formal diketahui memang kepala sekolah merupakan kunci bagi pengembangan dan peningkatan suatu sekolah. Indikator dari keberhasilan sekolah adalah jika sekolah tersebut berfungsi dengan baik, terutama jika prestasi belajar muridmurid dapat mencapai maksimal. (Arikunto, 1990:196).

Bagaimanapun, Kepala madrasah merupakan unsur vital bagi efektifitas lembaga pendidikan. Tidak akan pernah kita jumpai sekolah yang baik dengan Kepala Sekolah yang buruk atau sebaliknya sekolah yang buruk dengan Kepala Sekolah yang baik. Kepala madrasah yang baik akan bersikap dinamis dan menyiapkan berbagai macam program pendidikan. Bahkan tinggi rendahnya mutu suatu sekolah akan dipengaruhi oleh kepemimpinan di sekolah.

Kepala madrasah sebagai penentu kebijakan di sekolah juga harus memfungsikan perannya secara maksimal, pernyataan Kartini Kartono dalam buku Idochi Anwar menyebutkan bahwa fungsi kepemimpinan adalah memandu, menuntun, membimbing, memberi atau membangun motivasimotivasi kerja, mengemudikan organisasi, menjalin jaringan komunikasi yang lebih baik shingga akan mampu membawa para pengikutnya kepada tujuan yang telah direncanakan (Anwar, 2004:78).

Allah SWT berfirman:

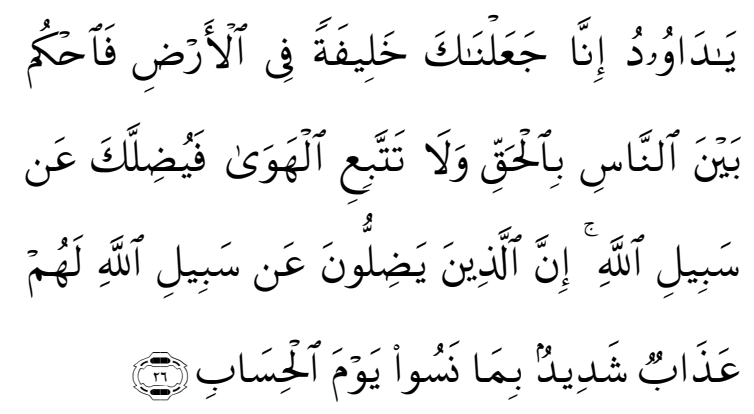

Artinya: "Hai Daud, Sesungguhnya Kami menjadikan kamu khalifah (penguasa) di muka bumi, Maka berilah keputusan (perkara) di antara manusia dengan adil dan janganlah kamu mengikuti hawa nafsu, karena ia akan menyesatkan kamu dari jalan Allah. Sesungguhnya orang-orang yang sesat darin jalan Allah akan mendapat azab yang berat, karena mereka melupakan hari perhitungan". (QS. Shad, 38: 26).

Dari penjelasan di atas, maka dapat dipahami bahwasanya posisi Kepala Sekolah akan menentukan arah suatu lembaga. Kepala Sekolah merupakan pengaturan dari program yang ada di sekolah. Karena nantinya diharapkan Kepala Sekolah dapat meningkatkan kompetensi professional guru, khususnya guru Pendidikan Agama Islam.

Dari pengertian diatas dapat disimpulkan bahwa Pengertian kepala Sekolah adalah tenaga fungsional guru yang diberi tugas untuk memimpin suatu lembaga dimana diselenggarakan proses belajar mengajar atau tempat dimana terjadi interaksi antara guru yang memberi pelajaran dan peserta didik yang menerima pelajaran.

\section{Peran dan Fungsi Kepala Madrasah}

Kepala Sekolah harus mampu melaksanakan pekerjaannya sebagai educator, menajer, administrator, dan suvervisor (EMAS). Akan tetapi dalam perkembangannya sesuai dengan kebutuhan masyarakat dan perkembangan zaman, Kepala Sekolah juga harus mampu berperan sebagai leader, innovator, dan motivator di sekolahnya. Dengan demikian dalam paradigma baru menajemen 
pendidikan, kepala sekolah setidaknya harus mampu berfungsi sebagai educator, manajer, administrator, suvervisor, leader, innovator dan motivator (Emaslim) (Mulyasa, 2007:25 97-98).

Fungsi kepemimpinan pendidikan terbagi atas: (1) Mengembangkan dan menyalurkan kebebasan berfikir dan mengeluarkan pendapat, baik secara perorangan maupun kelompok sebagai usaha mengumpulkan data atau bahan dari anggota kelompok dalam menetapkan kepemimpinan yang mampu memenuhi aspirasi di dalam kelompoknya. Dengan demikian keputsan akan dipandang sebagai sesuatu yang patut atau tepat untuk dilaksanakan oleh setiap anggota kelompok dalam rangka mencapai tujuan tertentu; (2) Mengembangkan suasana kerjasama yang efektif dengan memberikan pengharapan dan pengakuan terhadap kemampuan orang-orang yang dipimpinnya, sehingga timbul kepercayaan pada dirinya sendiri dan kesediaan menghargai orang lain sesuai dengan kemampuan masing-masing; dan (3) Membantu menyelesaikan masalahmasalah baik yang dihadapi secara perorangan maupun kelompok dengan memberikan petunjuk-petunjuk dalam mengatasinya sehingga berkembang kesediaan untuk memecahkannya dengan kemampuan sendiri (Shulhan, 2004: 55).

Adapun penjabaran dari tugas dan fungsi Kepala Sekolah adalah: Pertama, Kepala Madrasah sebagai Educator (Pendidik). Dalam melakukan fungsinya sebagai edukator, Kepala Sekolah harus memilki strategi yang tepat untuk meningkatkan profesionalisme tenaga kependidikan di sekolahnya. Menciptakan iklim sekolah yang kondusif, memberikan nasehat kepada warga sekolah, memberikan dorongan kepada seluruh tenaga 143

Vol. 14, No. 2, Oktober 2017 ISSN 1412-5382 kependidikan, serta melaksanakan model pembelajaran yang menarik, seperti team teaching, moving class, dan mengadakan program akselerisasi bagi peserta didik yang cerdas di atas normal (Mulyasa, 2007:99).

Sebagai seorang pendidik, kepala sekolah harus mampu menanamkan, memajukan dan meningkatkan empat macam nilai yaitu: (a) Mental, hal-hal yang berkaitan dengan sikap batin dan watak manusia; (b) Moral, hal-hal yang berkaitan dengan ajaran baik buruk mengenai perbuatan, sikap dan kewajiban atau moral yang diartikan sebagai akhlak, budi pekerti, dan kesusilaan; (c) Fisik, hal-hal yang berkaitan dengan kondisi jasmani atau badan, kesehatan dan penampilan manusia secara lahiriah; dan (d) Artistik, hal-hal yang berkaitan denga kepekaan manusia terhadap seni dan keindahan (Shulhan, 2004:55).

Dengan demikian dapat diambil pemahaman bahwa Kepala Sekolah sebagai educator harus memiliki kemampuan untuk membimbing guru, membimbing tenaga kependidikan non guru, membimbing peserta didik, mengembangkan tenaga kependidikan, mengikuti perkembangan IPTEK dan memberi contoh mengajar.

\section{Kedua, Kepala Madrasah} sebagai Manager. Menajemen pada hakekatnya merupakan suatu proses merencanakan, mengorganisasikan, melaksanakan, memimpin, dan mengendalikan usaha para anggota organisasi dalam rangka mencapai tujuan yang telah ditetapkan. Dikatakan suatu proses, karena semua menajer dengan ketangkasan dan keterampilan yang dimilikinya mengusahakan dan mendayagunakan berbagai kegiatan yang saling berkaitan untuk mencapai tujuan (Mulyasa, 2007:103).

Dari pemaparan di atas, dapat dipahami bahwa Kepala Sekolah sebagai menajer harus dapat

$$
\text { Jurnal Al-hikmah }
$$


mengantisipasi perubahan, memahami dan mengatasi situasi, mengakomodasi dan mengadakan orientasi kembali (Anwar, 2004:45).

\section{Ketiga, kepala madrasah} sebagai administrator. Kepala Sekolah sebagai Administrator memiliki hubungan yang sangat erat dengan berbagai aktivitas pengelolaan administrasi yang bersifat pencatatan, penyusunan, dan pendokumenan seluruh program sekolah. Secara spesifik, Kepala Sekolah harus memiliki kemampuan untuk mengelola administrasi peserta didik, mengelola administrasi personalia, mengelola administrasi sarana dan prasarana, mengelola administrasi kearsipan, dan mengelola administrasi keuangan. Kegiatan tersebut perlu dilakukan secara efektif dan efisien agar dapat menunjang produktivitas sekolah. Untuk itu, Kepala Sekolah harus mampu menjabarkan kemampuan di atas dalam tugas-tugas operasional (Mulyasa, 2007:107).

Dari penjelasan di atas, dapat diambil pemahaman bahwa KepalaSekolah sebagai administrator harus mampu mengelola semua perangkat KBM secara sempurna dengan bukti berupa data administrasi yang akurat serta mampu mengelola administrasi kesiswaan, ketenagaan, keuangan, saran dan prasarana, dan administrasi persuratan dengan baik sesuai dengan ketentuan yang berlaku.

\section{Keempat, kepala madrasah} sebagai Supervisor. Suvervisi ialah aktivitas pembinaan yang direncanakan untuk membantu para guru dan pegawai sekolah lainnya dalam melakukan pekerjaan mereka secara efektif. Fungsi pengawasan atau suvervisi dalam pendidikan bukan hanya sekedar kontrol melihat apakah segala kegiatan telah dilaksanakan sesuai dengan rencana atau program yang telah digariskan, tetapi lebih dari itu. Suvervisi mencakup penentuan kondisi atau syarat personil maupun material yang diperlukan untuk terciptanya situasi belajar mengajar yang efektif dan usaha memenui syaratsyarat itu (Purwanto, 2006:76).

Adapun, beberapa langkah yang perlu dikerjakan suvervisor antara lain: (a) Membimbing guru agar dapat memilih metode mengajar yang tepat; (b) Membimbing dan mengarahkan guru dalam pemiliham bahan pelajaran yang sesuai dengan perkembangan anak dan tuntutan kehidupan masyarakat; (c) Mengadakan kunjunagn kelas yang teratur, untuk observasi pada saat guru mengajar dan selanjutnya didiskusikan dengan guru; (d) Pada awal tahun baru baru, mengarahkan penyusunan silabus sesuai kurikulum yang berlaku; dan (e) Menyelenggarakan rapat rutin untuk membawa kurikulum pelaksanaannya di sekolah. Setiap akhir pelajaran menyelenggarakan penilaian bersama terhadap program sekolah.

Pada prinsipnya setiap tenaga kependidikan (guru) harus disupervisi secara periodik dalam melaksanakan tugasnya. Jika jumlah guru cukup banyak, maka Kepala Sekolah dapat meminta bantuan wakilnya atau guru senior untuk membantu melaksanakan supervisi. Keberhasilan Kepala Sekolah sebagai suvervisor antara lain dapat ditunjukkan oleh meningkatnya kesadara tenaga kependidikan (guru) untuk meningkatkan kinerjanya dan meningkatkannya keterampilan tenaga kependidikan (guru) dalam melaksanakan tugasnya.

Kelima, kepala madrasah sebagai Leader. Kepala Sekolah sebagai Leader harus mampu memberikan petunjuk dan pengawasan, meningkatkan kemauan tenaga kependidikan, membuka komunikasi dua arah, dan mendelegasikan tugas (Mulyasa, 2007:115). 
Dalam penerapannya, Kepala Sekolah sebagai Leader dapat dilihat dari tiga sifat kepemimpinan yaitu: demokratis, otoriter, dan bebas (laissez faire). Ketiga sifat tersebut sering dimiliki secara bersama oleh seorang leader, sehingga dalam melaksanakan kepemimpinannya, sifat-sifat tersebut muncul secara situasional (Purwanto, 2006:45).

Dari beberapa penjelasan di atas dapat diambil pemahaman bahwa Kepala Sekolah sebagai leader dalam melaksanakan tugasnya dapat menggunakan strategi yang tepat, sesuai dengan kematangan para tenaga kependidikan, dan kombinasi yang tepat diantara perilaku tugas dan perilaku hubungan.

Keenam, kepala madrasah sebagai Innovator. Dalam rangka melakukan peran dan fungsinya sebagai innovator, Kepala Sekolah harus memiliki strategi yang tepat untuk menjalin hubungan yang harmonis dengan lingkungan, mencari gagasan baru,mengintegrasikan setiap kegiatan, memberikan teladan kepala seluruh tenaga kependidikan di sekolah, dan mengembangkan model-model pembelajaran yang inovatif (Mulyasa, 2007:118).

Jadi, dapat dipahami bahwa dalam melaksanakan serta menjalankan peran dan fungsinya sebagai innovator, Kepala Sekolah harus mampu mencari, menemukan dan melaksanakan berbagai pembaharuan di sekolah.

\section{Ketujuh, kepala Madrasah} sebagai Motivator. Sebagai motivator, Kepala Sekolah harus memiliki strategi yang tepat untuk memberikan motivasi kepada para tenaga kependidikan dalam melakukan berbagai tugas dan fungsinya.

Adapun tugas dan peran Kepala Sekolah sebagai motivator adalah: (a) Pengaturan Lingkungan Fisik. Lingkungan yang kondusif akan 145

Vol. 14, No. 2, Oktober 2017 ISSN 1412-5382 menumbuhkan motivasi tenaga kependidikan dalam melaksanakan tugasnya. Oleh karena itu, Kepala Sekolah harus mampu membangkitkan motivasi tega kependidikan agar dapat melaksanakan tugas secara optimal. Pengaturan fisik tersebut antara lain mencakup ruang kerja yang kondusif, ruang belajar, ruang perpustakaan, ruang laboratorium, bengkel, seta mengatur lingkungan sekolah yang nyaman dan menyenangkan; (b) Pengaturan Suasana Kerja. Suasana kerja yang tenang dan menyenangkan juga akan membangkitkan kinerja para tenaga kependidikan. Untuk itu Kepala Sekolah harus mampu menciptakan hubungan kerja yang harmonis dengan para tenaga kependidikan, serta menciptakan lingkungan sekolah yang aman dan menyenangkan; (c) Disiplin. Disiplin dimaksudkan bahwa dalam meningkatkan profesionalisme tenaga kependidikan di sekolah, Kepala Sekolah harus berusaha menanamkan disiplin kepada semua bawahannya. Melalui disiplin inidiharapkan dapat tercapai tujuan secara efektif dan efisien, serta dapat meningkatkan produktifias sekolah; (d) Beberapa Strategi yang dapat digunakan oleh Kepala Sekolah dalam membina disiplin para tenaga kependidikan adalah: (1) Membantu para tenaga kependidikan dalam mengembangkan pola perilakunya; (2) Membantu para tenaga kependidikan dalam meningkatkan standar perilakunya; dan Melaksanakan semua aturan yang telah disepakati bersama; (e) Dorongan. Keberhasilan suatu organisasi atau lembaga dipengaruhi oleh berbagai faktor, baik faktor yang datang dari dalam maupun yang datang dari lingkungan. Dari berbagai faktor tersebut, motivasi merupakan suatu faktor yang cukup dominan dan dapat menggerakkan faktor-faktor lain kearah efektifitas kerja, bahkan motivasi sering 
disamakan dengan mesin dan kemudi mobil, yang berfungsi sebagai penggerak dan pengarah; dan (f) Penghargaan. Penghargaan (reward) ini sangat penting untuk meningkatkan profesionalisme tenaga kependidikan dan untuk mengurangi kegiatan yang kurang kondusif. Melalui penghargaan ini para tenaga kependidikan dapat dirangsang untuk meningkatkan profesionalisme kerjanya secara positif dan kondusif. Pelaksanaan penghargaan dapat dikaitkan dengan prestasi tenaga kependidikan secara terbuka, sehingga mereka memiliki peluang untuk meraihnya. Kepala Sekolah harus berusaha menggunakan penghargaan ini secara tepat, efektif, dan efisien untuk menghindari dampak negative yang ditimbulkannya (Mulyasa, 2007: 118-119).

Jadi, dari pemaparan di atas dapat dipahami bahwa Kepala Sekolah sebagai motivator harus memiliki strategi yang tepat untuk memberikan motivasi kepada para tenaga kependidikan dalam melakukan berbagai tugas dan fungsinya.

\section{Upaya Kerja Sama Kepala Madrasah dengan Guru dalam Peningkatan Motivasi Belajar Siswa}

Salah satu cara yang ditempuh oleh kepala sekolah yaitu dengan melakukan kerja sama dengan guru dari berbagi bidang seperti dalam bidang kesenian, olah raga, yang tujuannya adalah untuk meningkatkan motivasi belajar siswa, di antara kerja sama yang dilakukan oleh kepala sekolah dan guru adalah : (a) Melibatkan guru dalam rangka meningkatkan kualitas dan kuantitas siswa; (b) Melibatkan pendidik (guru) dalam setiap eventevent pendidikan, pelatihan, kegiatankegiatan siswa yang menunjang dalam pendidikan dan sosial; dan (c) Melibatkan guru mata pelajaran untuk peningkatan kemampuan dalam pendidikan/ pengajaran (Seminar, KKG, Musyawarah Gugus, Pelatihan Pengajaran).

Dalam melaksanakan kerja sama kepala sekolah dan guru berlandaskan pada kebersamaan, kepercayaan karena yakin bahwa kegiatan akan terlaksana dengan baik sesuai dengan tujuan jika ada kepercayaan dan dilaksanakan secara bersama. Kerja sama yang dilaksanakan oleh guru dan kepala sekolah dengan tujuan dianatanya adalah untuk mengatasi masalah yang dihadapi oleh guru dan siswa dalam kegiatan belajar mengajar, Kepala sekolah dalam menghadapi masalahmasalah yang timbul di lingkungan sekolah, melalui berbagai cara yaitu: (a) Membicarakan dengan staf / wakil dan personil yang terkait; (b) Mendiskusikan permasalahan yang ada; (c) Mengambil kesimpulan dari hasil diskusi tersebut; dan (d) Mengambil tindakan yang tepat sebagai pemecahan permasalahan.

Selain cara di atas kepala sekolah dalam mengatasi masalah yang di hadapi tidak langsung memberikan solusi akan tetapi kepala sekolah hanya memberikan ide, gambaran, masukan mengenai berbagai informasi yang berkaitan dengan kegiatan pembelajaran, sehingga guru mampu menentukan solusi /jalan keluar yang tepat untuk menghadapi masalah yang berkaitan dengan PBM / KBM, jadi kepala sekolah berfungsi sebagai motivator, fasilitator dan mediator.

Dalam melaksanakan kerja sama dengan guru kepala sekolah memiliki posisi yang dinamis, yaitu di sesuaikan dengan kondisi kepala sekolah memposisikan sebagai pemimpin dalam kondisi tertentu dan sebagai rekan kerja pada saat pelaksanaan kerja sama. Kerja sama di lihat secara kasat mata, memberikan dampak positif karena dengan kerja sama semua pekerjaan 
akan mudah untuk di kerjakan dianatara dampak positifnya adalah: (a) Guru mata pelajaran dapat meningkatkan kemampuannya/ kompetensinya; (b) Menimbulkan semanagt kerja karena merasa dihargai dan diperhatikan; (c) Lebih peka terhadap perubahn lingkungan; (d) Dapat meningkatkan kepercayaan guru terhadap sekolah; (e) Kegiatan sekolah dapat berjalan dengan baik/lancar; dan (f) Rasa memiliki terhadap sekolah tinggi (Http. Beringin komputer. Blogspot .com /2017/02/kerja- samakepala- sekolah-dengan-guru.htm).

\section{Hakikat Madrasah Unggulan}

Kata Madrasah secara etimologi merupakan isim makan yang berarti tempat belajar, dari kata darasa yang bararti belajar. Sedangkan secara terminologi istilah madrasah adalah nama atau sebutan bagi sekolah agama Islam, tempat proses belajar mengajar agama Islam secara formal yang mempunyai kelas dan memiliki kurikulum (Dewan Redaksi Ensiklopedi Islam, 2002: 105).

Karenanya, istilah madrasah tidak hanya diartikan sekolah dalam arti sempit, tetapi juga bisa dimaknai rumah, istana, kuttab, perpustakaan, surau, masjid, dan lain-lain. Bahkan juga seorang ibu bisa dikatakan sebagai Madrasah Pemula. Madrasah adalah lembaga pendidikan Islam yang telah dikenal sejak lama bersamaan dengan masa penyiaran Islam di Nusantara. Pengajaran dan pendidikan agama Islam timbul secara alamiah melalui proses akulturasi yang berjalan secara halus, perlahan dan damai sesuai dengan kebutuhan masyarakat sekitar (Irsal, 2003: 1).

Madrasah unggul merupakan lembaga pendidikan yang lahir dari sebuah keinginan untuk memiliki madrasah yang mampu berprestasi di tingkat nasional dan dunia dalam 147

Vol. 14, No. 2, Oktober 2017 ISSN 1412-5382 penguasaan ilmu pengetahuan dan teknologi serta ditunjang oleh akhlakul karimah. Madrasah unggul dikembangkan untuk mencapai keistimewaan dalam keluaran pendidikannya. Untuk mencapai keistimewaan tersebut, maka dimasukkan proses pendidikan, guru dan tenaga kependidikan, manajemen, layanan pendidikan, serta sarana penunjangnya harus diarahkan untuk menunjang tercapainya tujuan tersebut.

Adapun ciri-ciri Madrasah unggul adalah Madrasah yang memiliki indikator sebagai berikut: (a) Prestasi akademik dan non-akademik di atas rata-rata sekolah yang ada di daerahnya; (b) Sarana dan prasarana dan layanan yang lebih lengkap; (c) Sistem pembelajaran lebih baik dan waktu belajar lebih panjang; (d) Melakukan seleksi yang cukup ketat terhadap pendaftar; (e) Mendapat animo yang besar dari masyarakat, yang dibuktikan banyaknya jumlah pendaftar dibanding dengan kepasitas kelas; dan (f) Biaya sekolah lebih tinggi dari sekolah disekitarnya.

Departemen Agama sebagai salah satu pelaksana program pendidikan sekolah telah mengembangkan beberapa jenis madrasah unggulan, yaitu: Madrasah Aliyah Keagamaan, Madrasah Tsanawiyah Terbuka, Madrasah Model, Madrasah Aliyah Unggulan dan Madrasah Aliyah Ketrampilan.Strategi Kementerian Agama dalam mengembangkan madrasah unggulan dilakukan melalui langkah - langkah sebagai berikut: (1) Peningkatan mutu jenjang pendidikan pada perguruan agama islam sesuai dengan perkembangan ilmu dan teknologi; (2) Pembinaan madrasah negeri diusahakan menjadi contoh bagi madrasah swasta terutama dalam soal mutu; dan (3) Pembinaan madrasah swasta diusahakan agar system 
pendidikannya selaras dengan system pendidikan nasional.

Apa dan bagaimana karakteristik madrasah unggul atau madrasah model itu. Secara teoritis bisa diklasifikasi ke dalam beberapa kriteria, antara lain; keunggulan proses pembelajaran, keunggulan sarana-prasarana atau fasilitas belajar, keunggulan lingkungan pendidikan, keunggulan kognitif, keunggulan ekstrakuriler, keunggulan mulok, keunggulan life skill, keunggulan administrasi, dan lain-lain. Tentu yang dikehendaki adalah keunggulan multivariate. Kemendikbud umpamanya, menetapkan kriteria sekolah unggul sebagai berikut: (1) Insput siswa melalui seleksi yang ketat berdasarkan kriteria dan standar; (2) Sarana prasarana belajar yang memadai, baik intra maupun ekstra; (3) Lingkungan sekolah yang kondusif; (4) Guru dan tenaga kependidikan yang memiliki kualifikasi sesuai dengan persyaratan dan ketetapan Undangundang Guru dan Dosen tahun 2005; (5) Kurikulum yang diperkaya, yang mampu mengembangkan dan memfasilitasi potensi, bakat, kreasi siswa; (6) Rentang waktu belajar di sekolah lebih panjang; (7) Proses belajar mengajar yang berkualitas; (8) Perlakuan tambahan di luar kurikulum nasional; dan (9) Menjadi pusat keunggulan bagi sekolah-sekolah di sekitarnya (Http. Nurul Millah 1969. blogspot. Com /2012/07/v- behaviorurl defaultvmlo. htm).

Secara ontologis sekolah unggul dalam perspektif Departemen Pendidikan Nasional adalah sekolah yang dikembangkan untuk mencapai keunggulan dalam keluaran (output) pendidikannya. Untuk mencapai keunggulan tersebut maka masukan (input), proses pendidikan, guru dan tenaga kependidikan, manajemen, layanan pendidikan, serta sarana penunjangnya harus diarahkan untuk menunjang tercapainya tujuan tersebut.

Dari pengertian di atas dapat disimpulkan bahwa Pengertian Madrasah Unggulan adalah nama atau sebutan bagi sekolah agama Islam, tempat proses belajar mengajar agama Islam secara formal yang mempunyai kelas dan memiliki kurikulum.

\section{Setrategi Pengembangan Madrasah Unggulan}

Madrasah unggulan dimaksudkan sebagai center for excellence. Madrasah Unggulan diproyeksikan sebagai wadah menampung putra-putri terbaik masing-masing daerah untuk dididik secara maksimal tanpa harus pergi ke daerah lain. Dengan demikian terjadinya eksodus SDM terbaik suatu daerah ke daerah lain dapat diperkecil, dan sekaligus menumbuhkan persaingan sehat antara daerah dalam menyiapkan SDM mereka.

Karena menjadi center for excellence anak-anak terbaik, maka kesempatan belajar di kedua jenis madrasah ini haruslah melalui proses seleksi yang ketat dan dengan berbagai kententuan lainnya. Madrasah ini diperkuat oleh keberadaan majlis madrasah yang juga memiliki peran penting dalam pengembangannya. Secara lebih detail dapat dijelaskan sebagai berikut: (a) Aspek Administrasi, yaitu: (1) Maksimal 3 kelas untuk tiap angkatan; (2) Tiap kelas terdiri dari 25 siswa; (3) Rasio guru kelas adalah 1: 25; (4) Dokumentasi perkembangan tiap siswa dari mulai MI sampai PT; dan (5) Transparan dan Akuntabel; (b) Aspek Ketenagaan Kepala madrasah, yaitu: (1) Minimal S-2 untuk MA, S-1 untuk MTs dan MI; (2) Pengalaman Minimal 5 tahun menjadi kepala di sebuah madrasah; (3) Mampu berbahasa Arab dan atau Inggris; (4) Lulus tes (fit \& 
proper test); (5) Sistem kontrak 1 tahun; dan (6) Siap tinggal di kompleks madrasah; (c) Guru Minimal S-1, yaitu: (1) Spesialisasi sesaui mata pelajaran; (2) Pengalaman mengajar minimal 5 tahun; (3) Mampu berbahasa Arab dan atau Inggris; (4) Lulus tes (fit \& proper test); dan (5) Sistem kontrak 1 tahun; (d) Tenaga lain, yaitu: (1) Minimal S-1; (2) Spesialisasi sesuai bidang tugas; dan (3) Pengalaman mengelola minimal 3 tahun; (c) Aspek Kesiswaan, yaitu (1) Input, yang terdiri dari Lima besar MTs (untuk MA), Lima besar MI ( untuk MTs), Mampu berbahasa Arab dan Inggris dan Lulus Test; dan (2) Out Put, yang terdiri dari Menguasai berbagai disiplin ilmu, Ada keahlian spesifik tertentu, Mampu berbahasa dan menulis Arab dan Inggris secara benar, Terampil menulis dan berbicara (Indonesia), dan siap bersaing untuk memasuki universitas/institute bermutu dalam dan luar negeri (Departemen Agama RI, 2004 : 53-56); (d) Aspek Kultur Belajar, yaitu: (1) Student centered leaning ( pusat pembelajaran); (2) Student inquiry (kemampuan berpikir siswa); (3) Kurikulum dikembangkan secara lokal dengan melibatkan semua komponen madrasah termasuk siswa; (4) Bahasa pengantar Arab dan Inggris; (5) Bahasa pergaulan sehari-hari adalah Arab/Inggris; (6) Sistem Drop-Out ( hasil belajar); dan (7) Pendekatan belajar dengan fleksibelitas tinggi dengan mengikuti perkembangan metode-metode pembelajaran terbaru; dan (e) Aspek Sarana Prasarana, yaitu: (1) Perpustakaan yang memadai; (2) Laboratorium (Bahasa, IPA dan Matematika); (3) Perkebunan/ perkolaman sebagai laboratorium alam; (4) Musholla; dan Lapangan/Fasilitas olah raga (Bola kaki, basket dll) (Departemen Agama RI, 2004 : 53-56).

\section{Karakteristik Madrasah/ Sekolah Unggulan}

Departemen Pendidikan Nasional telah menetapkan sejumlah kriteria yang harus dimiliki sekolah/ madrsah unggul: (a) Masukan (input) berupa siswa yang diseleksi secara ketat. Dengan menggunakan ktriteria tertentu dan prosedur yang dapat dipertanggung jawabkan. Kriteria yang digunakan itu meliputi: (1) Prestasi belajar siswa yang superior dengan indikator angka raport, danem, dan hasil tes akademik lainnya; (2) Skor-skor tes yang meliputi intelegensi dan kreativitas; dan (3) Tes fisik; (b) Sarana dan prasarana yang menunjang untuk memenuhi kebutuhan belajar siswa serta dapat menyalurkan minat dan bakatnya, baik dalam bidang kurikuler maupun ekstrakurikuler; (c) Lingkungan belajar yang kondusif, baik lingkungan fisik maupun social psikologis; (d) Kurikulum yang diperkaya yaitu kurikulum yang dilakukan pengembangan improvisasi secara maksimal sesuai tuntunan belajar siswa peserta didik yang mempunyai keunggulan tersebut sehingga perlu dilakukan pengayaan dan/atau percepatan kurikulum; (e) Rentang waktu belajar disekolah lebih panjang sehingga perlu disediakan sarana dan prasarana penunjang; (f) Proses belajar mengajar yang berkualitas dan hasilnya dapat dipertanggungjawabkan kepada siswa, lembaga dan masyarakat; (g) Nilai sekolah unggul terletak pada perlakuan tambahan diluar kurikulum nasional melalui pengembangan materi kurikulum, program pengayaan dan perluasan serta percepatan, pengajaran remedial pelayanan bimbingan dan konseling, pembinaan dan disiplin serta kegiatan ekstrakurikuler lainnya; dan (h) Sekolah unggul diproyeksikan untuk menjadi pusat keunggulan bagi sekolahsekolah disekitarnya, sehingga mampu 
memberikan resonansi kepada lingkungan disekitarnya.

\section{Konsep Pangembangan Madrasah Unggulan}

Terdapat beberapa aspek yang harus diperhatikan oleh madrasah/ sekolah unggulan. Aspek-Aspek Keunggulan pada Madrasah/Sekolah Unggulan

secara umum sehingga dapat dikategorikan unggul harus meliputi tiga aspek. Ketiga aspek tersebut adalah : (1) Input . Daniel Goleman, dalam bukunya, menyebutkan bahwa kemampuan mengenal diri dan lingkungannya adalah kemampuan untuk melihat secara objektif atau analisis, dan kemampuan untuk merespon secara tepat, yang membutuhkan kecerdasan otak/Intelligence Quotien (IQ) dan kecerdasan emosional/Emotional Quotien (EQ). Di samping itu, kecerdasan spiritual/Spiritual Quotien (SQ) calon siswa hendaknya dapat terukur saat seleksi siswa baru. Dengan demikian, tes seleksi siswa baru hendaknya dapat mengukur ketiga aspek kecerdasan atau bahkan dapat mengukur berbagai kecerdasan/multy intellegence. (Http. Ainiazahra. blogspot. Com /2017/02/ makalah- tentangsekolah-unggulan. html); (2) Proses. Proses belajar-mengajar sekolah unggul ini setidaknya berkaitan dengan kemampuan guru, fasilitas belajar, kurikulum, metode pembelajaran, program ekstrakurikuler, dan jaringan kerjasama; dan (3) Kemampuan guru. Sekolah unggul harus memiliki guru yang unggul juga. Artinya, guru tersebut harus profesional dalam melaksanakan proses belajar-mengajar. Adapun kompetensi guru yang memungkinkan untuk mengembangkan suatu lembaga pendidikan yang unggul adalah: (a) Kompetensi penguasaan mata pelajaran; (b) Kompetensi dalam pembelajaran; (c) Kompetensi dalam pembimbingan; (d) Kompetensi komunikasi dengan peserta didik; dan (e) Kompetensi dalam mengevaluasi.

Pembelajaran bisa dikatakan efektif, bila guru mampu memberikan pengalaman baru bagi siswanya, membentuk kompetensi siswa, serta melibatkan peserta didik dalam perencanaan pelaksanaan dan penilaian pembelajaran.

Selanjutnya, ada beberapa penelitian yang relevan mengenai masalah ini dan sepanjang pengetahuan penulis belum ditemukan judul yang sama dengan penelitian ini. Adapun peneltian yang relevan misalnya, penelitian oleh Santi, dengan judul: "Strategi Guru PAI dalam Meningkatkan Prestasi Belajar Siswa pada Mata Pelajaran PAI Unggulan di MTS Nurul Ilmi Kecamatan Siak Hulu Pasir Putih Kampar." Penelitian ini bertujuan untuk mengetahui strategi Guru PAI dalam meningkatkan prestasi belajar siswa pada mata pelajaran PAI Unggulan di MTs Nurul Ilmi kecamatan Siak Hulu Pasir Putih Kampar. Dari penelitian tersebut didapati "baik" dengan persentasi tertinggi 90\%. (Eka Wahyuni, 2006:xvii).

Tesis Rahma (2013), dengan judul: "Upaya Kepala Sekolah dalam Meningkatkan Mutu Kegiatan Belajar Mengajar (KBM) di SMP Negeri di Kecamatan Maja pada Program Studi Pendidikan Agama Islam Program Pascasarjasan Institut Agama Islam Negeri (IAIN) (Syekh Nurjati, Cirebon 2013)." Penelitian ini bertujan untuk mengetahui upaya Kepala Sekolah dalam Meningkatkan Mutu Kegiatan Belajar Mengajar (KBM). Dari penelitian tersebut didapati "baik" dengan persentasi tertinggi $82,4 \%$.

Adapun, persamaan penelitian tersebut dengan penilitian ini adalah sama-sama meneliti tentang strategi 
Kepala Madrasah dalam mewujudkan Madrasah Unggulan. Sedangkan perbedaan penelitian dengan penelitian terdahulu yakni tempat penelitian, populasi, dan sampel penelitian dari jenis objek penelitiannya maupun subjek penelitiannya.

Penelitian ini berkaitan dengan konsep Strategi Kepala Madrasah dalam mewujudkan Madrasah Unggulan di MIN 3 Simpang Tiga Kecamatan Bukit Raya Kota Pekanbaru.

Berdasarkan uraian indikator pada konsep operasional diatas, maka dapat dirumuskan kerangka konseptual pada penelitian ini, yaitu terdiri dari: (1) Aspek Administrasi; (2) Aspek Ketenagaan Kepala madrasah; (3) Guru Minimal S-1; (4) Aspek Kesiswaan; (5) Aspek Kultur Belajar; dan (6) Aspek Sarana Prasarana.

\section{METODE}

Jenis penelitian yang digunakan dalam penelitian ini adalah metode kualitatif. Dapat diartikan sebagai penelitian yang berfungsi untuk mendeskripsikan atau memberi gambaran terhadap objek yang diteliti melalui data sampel atau populasi sebagaimana adanya tanpa melakukan analisis dan membuat kesimpulan yang berlaku untuk umum.

Berdasarkan judul penelitian ini, maka tempat penelitian ini adalah di MIN 3 Simpang Tiga Kecamatan Bukit Raya Kota Pekanbaru. Penelitian ini akan memakan waktu selama empat bulan, yaitu dimulai pada bulan Desember 2016 sampai dengan bulan Maret tahun 2017.

Subjek penelitian ini adalah Kepala MIN 3 Simpang Tiga Kecamatan Bukit Raya Kota Pekanbaru. Sedangkan objek penelitian ini adalah strategi Kepala Madrasah dalam mewujudkan madrasah unggulan. Informan dalam penelitian ini adalah satu orang kepala 151

Vol. 14, No. 2, Oktober 2017 ISSN 1412-5382 sekolah.

Untuk memperoleh data yang diperlukan dalam penelitian ini, maka penulis menggunakan teknik sebagai berikut: (1) Data Primer yaitu data yang diperoleh atau dikumpulkan oleh peneliti secara langsung dari sumber datanya. Data primer disebut juga sebagai data asli atau data baru yang memiliki sifat up to date. Untuk mendapatkan data primer, peneliti harus mengumpulkan data primer ini adalah dengan cara wawancara; dan (2) Data Sekunder yaitu data yang diperoleh atau dikumpulkan peneliti dari berbagai sumber yang telah ada, seperti dokumen. Dokumen yaitu datadata yang diperoleh dari pihak sekolah berupa dokumen-dokumen yang dapat melengkapi data yang dibutuhkan (Arikunto,1993:23).

Pengolahan data dikerjakan secara manual dan bersifat deskriptif. Jawaban dari hasil wawancara dan dilakukan pentabulasian guna memudahkan untuk melakukan interpretasi. Pengolahan data dilakukan setelah semua data terhimpun dan telah dapat memberikan gambaran yang menyeluruh tentang objek penelitian.

Setelah data diperoleh dan diolah dari hasil wawancara disjikan dalam bentuk uraian kalimat yang jelas dan rinci, kemudian data dianalisa dengan berpedoman dan berpandangan kepada teori atau pendapat para ahli yang berkaitan erat dengan penelitian. Berdasarkan analisis tersebut akan ditarik kesimpulan terhadap pelaksanaan mewujudkan madrasah unggulan apakah sudah memenuhi kriteria yang baik dan sesuai dengan prosedur pelaksanaan mewujudkan madrasah unggulan?.

Untuk menganalisa penelitian ini, maka dilakukan dengan langkahlangkah sebagai berikut:

Pengumpulan informasi, melalui wawancara maupun observasi Jurnal Al-hikmah 
langsung; (2) Reduksi, langkah ini adalah untuk memilih informasi mana yang sesuai dan tidak sesuai dengan masalah penelitian; (3) Penyajian, setelah informasi dipilih maka disajikan bisa dalam bentuk uraian penjelasan; dan (4) Tahap akhir, adalah menarik kesimpulan (Faizah, 2011: 52).

\section{HASIL}

\section{Gambaran Umum MIN 3 Simpang Tiga Kecamatan Bukit Raya Kota Pekanbaru}

Departemen Agama lewat kebijakannya menyadari upaya sosialisasi lembaga pendidikan islam, dalam ungkapan lain yakni lembaga pendidikan Islam Khususnya Madrasah Ibtidaiyah. Melihat kepada hal tersebut pemuka masyarakat Simpang Tiga khususnya dan masyarakat kota pekanbaru pada umumnya mengingat anak-anak mereka yang semakin hari semakin bertambah dan kurangnya pendidikan agama islam.

Madrasah Ibtidaiyah yang merupakan lembaga pendidikan dasar yang bercirikan islam yang sejajar dengan Sekolah Dasar (SD) adalah merupakan suatu jenjang pendidikan yang diharapkan dapat merubah moral anak-anak mereka. Maka sepakatlah untuk mendirikan suatu pendidikan yang diberi nama Madrasah Ibtidaiyah (MI). Madrasah Ibtidaiyah Negeri 3 Simpang Tiga Kota Pekanbaru beralamat di jalan tengku Bey No 72 Kelurahan Simpang Tiga Kecamatan Bukit Raya Kota Pekanbaru Provinsi Riau. Madrasah ini berdiri pada tanggal 01 juli 1992, pada saat berdiri madrasah ini merupakan madrasah sawasta yang dikelola oleh madrasah dilingkungan masjid muslimin yang bernama Madrasah Ibtidiyah Swasta Muslimin.

Pada awalnya, adalah seorang kepala Madrasah Ibtidaiyah Swasta
Muslimin, yakni NUR'AINI Z. yang merupakan salah satu Pegawai Negeri Sipil dilingkungan Departemen Agama Kota Pekanbaru. Kepala Madrasah Ibtidaiyah Negeri Swasta Muslimin dipercayakan masyarakat karena ibu Nur'aini Z. merupakan seorang yang sangat aktif di masyarakat terutama dalam kegiatan keagamaan dan disiplin dalam menjalankan tugas sebagai guru. Adapun tujuan dari berdirinya madrasah ini adalah: (1) Berupaya untuk membentuk manusia muslim agar menjadi manusia yang beriman dan taqwa, berguna bagi masyarakat, bangsa, negara dan agama; (2) Membentuk manusia yang berakhlak mulia dan berbudi pekerti yang luhur, jujur, berdisiplin menjadi muslim sejati; dan (3) Agar menjadi anak yang saleh dan senantiasa mendo'akan kedua orang tua.

Pada awal berdirinya madrasah ini menempati tanah dengan ukuran 40 x 80 M atau sekitar 3200 M2 dan bangunan pertama dengan ukuran $16 \mathrm{x}$ $6 \mathrm{M}$ atau sekitar 3200 M2 dengan jumlah siswa 7 oarang siswa dan 4 tahun berikutnya berjumlah 66 siswa terdiri dari 4 kelas dengan jumlah guru 5 orang yaitu guru pegawai Negeri Sipil yang doperbantukan 2 orang dan 3 orang guru honorer.

Karena adanya perkembangan dunia pendidikan dari masa kemasa, begitu juga dengan Madrasah Ibtidaiyah Swasta Muslimin, pada akhir tahun 2003 Madrasah Ibtidaiyah swasta Muslimin berubah status dan menjadi Negeri dan berganti nama menjadi Madrasah Ibtidaiyah Negeri 3 Simpang Tiga Kota Pekanbaru. Begitu juga dengan unsur pimpinan pada Madrasah Ibtidaiyah Negeri 3 Kota Pekanbaru dari tahun ketahun mengalami berbagai perkembangan dan perubahan. Setelah masa kepemimpinan Ibu Nur'aini Z., begitu Madrasah ini dinegerikan, jabatan kepala Madrasah di gantikan 
oleh Ibu Dra. Hj. Rahmawati yang dalam masa kepemimpinannya Madrasah Ibtidaiyah Negeri 3 Simpang Tiga Kota Pekanbaru terus mengalami berbagai perubahan menuju kemajuan dunia pendidikan.

Adapun visi Madrasah Ibtidaiyah Negeri (MIN) 3 Kota Pekanbaru adalah: "Terwujudnya cendikia yang qur'ani dan berwawasan lingkungan dan Madrasah unggulan". Sedangkan misi Madrasah Ibtidaiyah Negeri (MIN) 3 Kota Pekanbaru adalah: "(1) Meningkatkan kualitas pembelajaran yang berbasis Pikem, sriritual,, dan berwaawasan lingkungan; (2) Meningkatkan prestasi dibidang alqur'an, sains, seni, dan olahraga; (3) Mengembangkan budaya gemar membaca, berkarya, dan bekerja; (4) Meningkatkan kepedulian dan kecintaan terhadap pemeliharaan, pengelolaan,dan pelestarian lingkungan hidup; (5) Menanamkan rasa tanggungjawab terhadap pencegahan kerusakan dan pencemaran lingkungan; dan (6) Mengembangkan pemanfaatan limbah dan sampah menjadi berdaya guna.

Perkembangan terus terjadi di Madrasah Ibtidaiyah Negeri 3 Simpang Tiga Kota Pekanbaru, setelah masa ibu Dra. Hj. Rahmawati, maka pada akhir tahun 2005 jabatan kepala Madrasah digantikan oleh Bapak Nazir L, S.PdI hingga sekarang. Sementara itu pada masa Bapak Nazir L, S.Pd.I jabatan ketua komite Madrasah Ibtidaiyah Negeri 3 Simpang Tiga Kota Pekanbaru dijabat oleh Bapak Suharto Priode 2005 s/d 2007 dan priode 2008 sampai sekarang di jabat oleh bapak ALMusatta. Bapak Al Musatta ini hingga saat ini sudah menjabat sebagai ketua komite Madrasah Ibtidaiyah Negeri 3 Simpang Tiga Kota Pekanbaru sebanyak dua kali periode yang mana beliau menggantikan posisi Bapak Suharto sebagai mantan ketua Komite Madrasah 153

Vol. 14, No. 2, Oktober 2017 ISSN 1412-5382
Ibtidaiyah Negeri 3 Simpang Tiga kota Pekanbaru, adapun nama-nama Komite dari berdirinya MI Muslimin sampai sekarang adalah sebagai berikut: Ibu Elni, BA, Bapak Sahif, SH, Bapak Suharto, Bapak Al-Musatta, Bapak Zulkifli, S.Pd dan Darwin, ST.

Guru adalah salah satu unsur dalam dunia pendidikan. Oleh karena itu, keberadaan seorang guru sangat menentukan keberhasilan suatu lembaga pendidikan, tanpa seorang guru, maka tujuan pendidikan tidak akan tercapai. Guru atau tenaga pengajar di MIN 3 Simpang Tiga Kecamatan Bukit Raya Kota Pekanbaru.Secara keseluruhan guruguru yang mengajar di MIN 3 Simpang Tiga Kecamatan Bukit Raya Kota Pekanbaru pada tahun 2016-2017 berjumlah 34 orang yang berasal dari berbagai lembaga pendidikan dan mengajar berbagai mata pelajaran yang diajarkan di diMIN 3 Simpang Tiga Kecamatan Bukit Raya Kota Pekanbaru.

Dalam proses belajar mengajar siswa merupakan salah satu komponen yang penting. Oleh karena itu pengetahuan tentang jumlah siswa sangat penting, guna mengetahui perkembangan siswa. Adapun keadaan guru di MIN 3 Simpang Tiga Kecamatan Bukit Raya Kota Pekanbaru terdiri dari 21 guru yang merupakan lulusan S1 dan S2.

\section{Strategi Kepala Madrasah dalam mewujudkan Madrasah Unggulan di MIN 3 Simpang Tiga Kecamatan Bukit Raya Kota Pekanbaru.}

Penyajian data pada bab ini berdasarkan pada hasil penelitian yang dilakukan di MIN 3 Simpang Tiga Kecamatan Bukit Raya Kota Pekanbaru tentang Upaya Guru PAI Dalam Meningkatkan Profesionalisme Guru di MIN 3 Simpang Tiga Kecamatan Bukit Raya Kota Pekanbaru. Data yang akan Jurnal Al-hikmah 
disajikan pada bab ini diperoleh dari wawancara yang penulis lakukan kepada kepala sekolah MIN 3 Simpang Tiga Kecamatan Bukit Raya Kota Pekanbaru.

Hasil Wawancara dengan Kepala Sekolah Strategi Kepala Madrasah dalam mewujudkan Madrasah Unggulan di MIN 3 Simpang Tiga Kecamatan Bukit Raya Kota Pekanbaru

Berdasarkan hasil wawancara strategi kepala madrasah dalam mewujudkan madrasah unggulan di MIN 3 Simpang Tiga Kecamatan Bukit Raya Kota Pekanbaru bahwa adalah:

\section{Aspek Administrasi}

Apakah setiap penerimaan murid baru (PMB) bapak Memaksimalkan 3 kelas untuk tiap angkatan yang diterima?

Jawab: Animo masyarakat ke MIN 3 ini luar biasa. Kemaren kita buka tahun 2015-2016 pendaftaran satu minggu kita terima 140 an itu yang mendaftar hampir 500 an, mudah-mudahan MIN 3 ini sudah menjadi pilihan utama orang tua. Saya sebagai kepala sekolah sudah tiga kali menerima siswa baru. Itu hampir separuh yang kami tolak. Alhamdulillah MIN 3 itu sudah jadi pilihan utama di simpang tiga ini, tapi yang paham dengan madrasah jadi kita menerima murid baru sesuai dengan kondisi sekolah, kita menerima 4 kelas.

Apakah di MIN 3 ini menjadikan rasio guru kelas 1 banding 25 ?

Jawab: Ya, Sudah sesuai dengan undang-undang memang harus seperti itu guru kelas 1 banding 25 jangan sampai melebihi, karena dikhawatirkan sulit untuk menciptakan kenyamanan dalam mengajar.
Apakah di MIN 3 ini mendokumentasikan perkembangan tiap siswa dari mulai MI sampai PT. Transparan dan Akuntabel?

Jawab: kalau mengenai dokumentasi perkembangan tiap siswa dari mulai MI sampai PT. Transparan dan Akuntabel tidak punyai, cuman yang kita punya adalah data alumni dari Min ini.

Aspek Ketenagaan Kepala Madrasah

Apakah setiap pengangkatan kepala Madrasah harus Menentukan pengalaman minimal 5 tahun menjadi kepala di sebuah madrasah ini?

Jawab: kalau mengenai pengangkatan kepala Madrasah memang harus mempunyai pengalaman yang banyak, bahkan harus lebih 5 tahun.

Apakah setiap kepala sekolah di MIN ini memastikan mampu berbahasa Arab atau Inggris?

Jawab: Tidak juga, cuman harus pandai walaupun tidak terlalu menguasai, alhamdulillah sy sebagai kepala sekolah sarjana agama juga bisa menterjemahkan bahasa Arab.

Apakah setiap guru yang mengajar di Madarasah ini menjadikan sistem kontrak 1 tahun siap tinggal di kompleks sekitar madrasah?

Jawab: kita tidak mempunyai aturan yang mengikat seperti itu, yang terpenting guru disiplin dalam mengajar, jangan sampai terlambat datang kesekolah.

\section{Guru Minimal S-1}

Apakah guru yang mengajar di Madrasah ini mesti mempunyai spesialisasi mata pelajaran yang diajarkan?

Jawab: Ya, sebagai kepala madrasah harus memberikan keleluasaan terhadap para guru sesuai spesialisasi 
mata pelajaran yang diajarkan, keleluasaan yang dimaksud, bukan berarti mereka lepas begitu saja. Oleh karena itu guru sangat kita harapkan, agar mereka kreatif, inovatif dan menyenangkan dan keleluasaan tadi kita berikan, untuk itu agar mereka bisa kreatif, inovatif dan menyenangkan.

\section{Apakah setiap penerimaan guru di Madarasah ini menjadikan pengalaman mengajar minimal 5 tahun?}

Jawab: Ya, memang harus seperti itu, sebagai kepala Sekolah sudah sewajarnya dan seharusnya dan itu merupakan suatu kewajiban bagi Kepala Sekolah dalam meningkatkan kemampuan para guru dalam menjalankan tugasnya, salah satunya, ya, kepala sekolah menerima guru di Madarasah ini mesti mempunyai pengalaman mengajar walaupun belum sampai 5 tahun tetap kita terima apalagi ini sekolah Negeri.

Apakah setiap guru yang mengajar di MIN ini harus mampu berbahasa Arab atau Inggris?

Jawab: tidak juga, tapi kita menyarankan kepada majlis guru untuk mempelajari bahasa asing seperti berbahasa Arab atau Inggris.

\section{Aspek Kesiswaan}

1) Input

Apakah siswa yang masuk Madrasah ini menjadikan syarat lulus test ketika masuk sekolah ini ?

Jawab: Alumni siswa yang sudah tamat dari Madrasah ini lulus test ketika masuk kesekolah lanjutan itu mayoritas alhamdulillah diterima di sekolah lanjutan unggulan ataupun faforit.

2) Output

Apakah alumni siswa yang sudah tamat dari Madrasah ini Menguasai berbagai disiplin ilmu ?

155

Vol. 14, No. 2, Oktober 2017 ISSN 1412-5382
Jawab: Yang jelas menurut hemat kami alumni kita sudah banyak yang masuk perguruan tinggi faforit, mungkin karena mereka sudah mempunyai ilmu.

Apakah alumni siswa yang sudah tamat dari Madrasah ini Ada keahlian spesifik tertentu yang mereka praktekkan di luar ?

Jawab: Alumni siswa yang sudah tamat dari Madrasah ini Ada keahlian, kalau membaca Al-Qur'an yes, pidato oke. Ditambah keahlian lain.

Apakah alumni siswa yang sudah tamat dari Madrasah ini Mampu berbahasa dan menulis Arab dan Inggris secara benar?

Jawab: satu dua ada juga, cuman tidak semua, kalau menulis arab santri kita bisa.

Aspek Kultur Belajar

Apakah kurikulum dikembangkan secara lokal dengan melibatkan semua komponen madrasah termasuk siswa di sekolah ini ?

Jawab: Ya, saya sebagai kepala sekolah harus memperhatikan itu, dan bahkan seperti yang tadi saya selalu menyarankan agar setiap guru mendayagunakan media dan sarana dalam proses pembelajaran sebagai seni dalam mengajar kalau mengenai kurikulum dikembangkan secara lokal dengan melibatkan semua komponen madrasah termasuk siswa di sekolah ini.

Apakah bapak/ibu mengupayakan ketika memulai pelajaran di Madarasah ini dengan menggunakan bahasa pengantar Arab dan Inggris? Jawab: Tidak, karena guru kita masih sebahagian yang sudah pandai bahasa Arab dan Inggris, tapi kita sedangb proses menuju kesana.

Aspek Sarana Prasarana 
Apakah bapak mengupayakan agar Perpustakaan ini bisa memadai ?

Jawab: Ada Perpustakaan di Madrasah ini, sarana ini penunjang dalam pembelajaran, namun biarpun demikian sarana tidak menjadi ukuran untuk kelancaran dalam proses pembelajaran. Seperti film Laskar pelangi yang sekolahnya disebuah desa terpencil dan sarana tidak memadai, akan tetapi proses pembelajaran berjalan dengan baik. Akan tetapi sarana itu penting sekali lagi sarana itu penunjang.

Apakah bapak mengupayakan agar di Madrasah ini mempunyai sarana laboratorium seperti Bahasa IPA dan Matematika?

Jawab: Ada, di Madrasah ini mempunyai sarana laboratorium seperti Bahasa IPA dan Matematika.

\section{Apakah di MIN 3 ini memiliki perkebunan / perkolaman sebagai laboratorium alam?}

Jawab: Kita punya kebun sekolah dan kolam ikan, sekolah kiat ini adalah sekolah adi wiyata.

\section{Apakah di MIN 3 mengadakan fasilitas seperti Musholla, lapangan fasilitas olah raga seperti bola kaki, basket dll ?}

Jawab: Ada mempunyai fasilitas seperti Musholla, lapangan fasilitas olah raga seperti bola kaki, Sarana adalah salah satu unsur penting dalam proses pembelajaran. Sarana ini penunjang dalam pembelajaran, namun biarpun demikian sarana tidak menjadi ukuran untuk kelancaran dalam proses pembelajaran.

\section{PEMBAHASAN}

Berdasarkan hasil wawancara yang telah dikemukakan di atas, maka dilakukan analisa terhadap data hasil penelitian secara berurutan sesuai dengan pokok permasalahan penelitian tentang Strategi Kepala Madrasah dalam mewujudkan Madrasah Unggulan di MIN 3 Simpang Tiga Kecamatan Bukit Raya Kota Pekanbaru.

Melalui hasil wawancara pada konsep peningkatan aspek administrasi di MIN 3 Simpang Tiga Kecamatan Bukit Raya Kota Pekanbaru. Bahwa penerimaan murid baru (PMB) mendapat Animo masyarakat ke MIN 3 ini luar biasa. Kemaren kita buka tahun 2015-2016 pendaftaran satu minggu kita terima 140 an itu yang mendaftar hampir 500 an, mudah-mudahan MIN 3 ini sudah menjadi pilihan utama orang tua. Saya sebagai kepala sekolah sudah tiga kali menerima siswa baru. Itu hampir separuh yang kami tolak.

Alhamdulillah MIN 3 itu sudah jadi pilihan utama di simpang tiga ini, tapi yang paham dengan madrasah jadi kita menerima murid baru sesuai dengan kondisi sekolah, kita menerima 4 kelas.

Sesuai rasio guru kelas 1 banding 25 Ya, Sudah sesuai dengan undangundang memang harus seperti itu guru kelas 1 banding 25 jangan sampai melebihi, karena dikhawatirkan sulit untuk menciptakan kenyamanan dalam mengajar. Selanjutnya dokumentasi perkembangan tiap siswa mengenai dokumentasi perkembangan tiap siswa dari mulai MI sampai PT. Transparan dan Akuntabel tidak punyai, cuman yang kita punya adalah data alumni dari Min ini.

Sedangkan pada konsep aspek ketenagaan kepala madrasah, setiap pengangkatan kepala Madrasah memang harus mempunyai pengalaman yang banyak, bahkan harus lebih 5 tahun. Dilihat dari berbahasa Arab atau Inggris harus pandai walaupun tidak terlalu menguasai, alhamdulillah sy sebagai kepala sekolah sarjana agama juga bisa menterjemahkan bahasa Arab. Sedangkan mengenai guru yang 
mengajar di Madarasah ini yang sudah dikontrak 1 tahun siap tinggal di kompleks sekitar madrasah, tidak mempunyai aturan yang mengikat seperti itu, yang terpenting guru disiplin dalam mengajar, jangan sampai terlambat datang kesekolah.

Pada konsep Guru Minimal S-1, guru yang mengajar di Madrasah ini sesuai spesialisasi mata pelajaran yang diajarkan, sebagai kepala madrasah harus memberikan keleluasaan terhadap para guru sesuai spesialisasi mata pelajaran yang diajarkan, keleluasaan yang dimaksud, bukan berarti mereka lepas begitu saja. Oleh karena itu guru sangat kita harapkan, agar mereka kreatif, inovatif dan menyenangkan dan keleluasaan tadi kita berikan, untuk itu agar mereka bisa kreatif, inovatif dan menyenangkan.

Setiap penerimaan guru di Madarasah ini mesti mempunyai pengalaman mengajar minimal 5 tahun, memang harus seperti itu, sebagai kepala Sekolah sudah sewajarnya dan seharusnya dan itu merupakan suatu kewajiban bagi Kepala Sekolah dalam meningkatkan kemampuan para guru dalam menjalankan tugasnya, salah satunya, ya, kepala sekolah menerima guru di Madarasah ini mesti mempunyai pengalaman mengajar walaupun belum sampai 5 tahun tetap kita terima apalagi ini sekolah Negeri.

Sedangkan guru yang mengajar di MIN ini harus mampu berbahasa Arab atau Inggris. Kepala sekolah menyarankan kepada majlis guru untuk mempelajari bahasa asing seperti berbahasa Arab atau Inggris. Pada Aspek Kesiswaan, alumni siswa yang sudah tamat dari Madrasah ini masuk lima besar MA, Alumni siswa kita yang sudah tamat dari Madrasah ini, sudah banyak alhamdulillah masuk dalam lima besar di MAN Model Pekanbaru.

Alumni siswa yang sudah tamat dari Madrasah ini lima besar MTs, 157

Vol. 14, No. 2, Oktober 2017 ISSN 1412-5382 alumni siswa kita yang sudah tamat dari Madrasah ini, sudah banyak alhamdulillah masuk juga dalam lima besar di MTsN Simpang Tiga Pekanbaru. Alumni siswa yang sudah tamat dari Madrasah ini lulus test ketika masuk kesekolah lanjutan di sekolah unggulan, Alumni siswa yang sudah tamat dari Madrasah ini lulus test ketika masuk kesekolah lanjutan itu mayoritas alhamdulillah diterima di sekolah lanjutan unggulan ataupun faforit.

Sedangkan pada out put siswa MIN 3, alumni siswa yang sudah tamat dari Madrasah ini Menguasai berbagai disiplin ilmu, Yang jelas menurut hemat kami alumni kita sudah banyak yang masuk perguruan tinggi faforit, mungkin karena mereka sudah mempunyai ilmu. Selanjutnya alumni siswa yang sudah tamat dari Madrasah ini Ada keahlian spesifik tertentu yang mereka praktekkan di luar, Alumni siswa yang sudah tamat dari Madrasah ini Ada keahlian, kalau membaca AlQur'an yes, pidato oke. Ditambah keahlian lain.

Alumni siswa yang sudah tamat dari Madrasah ini Mampu berbahasa dan menulis Arab dan Inggris secara benar, satu dua ada juga, cuman tidak semua, kalau menulis arab santri kita bisa. Aspek kultur belajar, kurikulum dikembangkan secara lokal dengan melibatkan semua komponen madrasah termasuk siswa di sekolah ini, sebagai kepala sekolah harus memperhatikan itu, dan bahkan seperti yang tadi saya selalu menyarankan agar setiap guru mendayagunakan media dan sarana dalam proses pembelajaran sebagai seni dalam mengajar kalau mengenai kurikulum dikembangkan secara lokal dengan melibatkan semua komponen madrasah termasuk siswa di sekolah ini.

Memulai pelajaran di Madarasah ini dengan menggunakan bahasa Jurnal Al-hikmah 
pengantar Arab dan Inggris, tidak, karena guru kita masih sebahagian yang sudah pandai bahasa Arab dan Inggris, tapi kita sedangb proses menuju kesana. Selanjutnya dilihat dari konsep aspek Sarana Prasarana. Sarana Perpustakaan di Madrasah ini memadai, Perpustakaan di Madrasah ini, sarana ini penunjang dalam pembelajaran, namun biarpun demikian sarana tidak menjadi ukuran untuk kelancaran dalam proses pembelajaran. Seperti film Laskar pelangi yang sekolahnya disebuah desa terpencil dan sarana tidak memadai, akan tetapi proses pembelajaran berjalan dengan baik. Akan tetapi sarana itu penting sekali lagi sarana itu penunjang.

Madrasah ini mempunyai sarana laboratorium seperti Bahasa IPA dan Matematika dan memiliki perkebunan / perkolaman sebagai laboratorium alam, punya kebun sekolah dan kolam ikan, sekolah kiat ini adalah sekolah adi wiyata. Mempunyai fasilitas seperti Musholla, lapangan fasilitas olah raga seperti bola kaki, basket dll. Mempunyai fasilitas seperti Musholla, lapangan fasilitas olah raga seperti bola kaki, Sarana adalah salah satu unsur penting dalam proses pembelajaran. Sarana ini penunjang dalam pembelajaran, namun biarpun demikian sarana tidak menjadi ukuran untuk kelancaran dalam proses pembelajaran.

\section{SIMPULAN}

Berdasarkan hasil temuan dan analisa data di atas, maka penulis dapat menyimpulkan bahwa strategi kepala madrasah dalam mewujudkan madrasah unggulan di MIN 3 Simpang Tiga Kecamatan Bukit Raya Kota Pekanbaruyaitu: peningkatan aspek administrasi, aspek ketenagaan kepala madrasah, guru minimal s-1, aspek kesiswaan, aspek kultur belajar dan aspek sarana prasarana. Kepala madrasah sudah menjalankan dengan baik.

Setelah meneliti lebih jauh tentang strategi kepala madrasah dalam mewujudkan madrasah unggulan di MIN 3 Simpang Tiga Kecamatan Bukit Raya Kota Pekanbaru, maka penulis dengan segala kerendahan hati ingin memberikan beberapa saran kepada pihak-pihak yang terkait dalam bentuk sumbangan pemikiran sebagai berikut: (1) Sebagai kepala sekolah supaya mempraktekkan strategi yang sudah dilakukan dalam mewujudkan madrasah unggulan di MIN 3; dan (2) Supaya kepala sekolah mempertahankan bahkan meningkatkan strategi yang sudah dibuat di MIN 3 ini dalam mewujudkan madrasah unggulan.

\section{DAFTAR RUJUKAN}

Anwar, Moch. Idochi. 2004. Administrasi Pendidikan dan Manajemen Biaya Pendidikan. Bandung: Alfabeta.

Arikunto, Suharsimi. 2007. Organisasi Dan Administrasi Pendidikan Teknologi Dan Kejuruan. Jakarta: CV. Raja Wali. 1993. Prosedur Penelitian Suatu Pendekatan Praktis. Jakarta: Rineka Cipta.

Bafadal, Ibrahim. 2003. Manajemen Peningkatan Mutu Sekolah Dasar: Dari Sentralisai Menuju Desentralisasi. Jakarta: Bumi Aksara.

Dairi, Rizal. 2008. Metodologi Penelitian. Pekanbaru: UIR Pres.

Dani, Sudarwan. 2007. Visi Baru Manajemen Sekolah Dari Unit Birokrasi Ke Lembaga Sekolah. Jakarta: PT. Bumi Aksara.

Dewan Redaksi Ensiklopedi Islam. 2002. Ensiklopedi Islam 3. Jakarta: Ichtiar Baru vanhoeve. 
Departeman Agama RI. 2005. Alqur'an Dan Terjemahan. Bandung: CV JART.

Departemen Agama RI. 2004. Desain Pengembangan Madrasah. Jakarta: Direktorat Jenderal Kelembagaan Agama Islam.

Faisah, Hasnah. 2011. Menulis Karangan Ilmiah. Pekanbaru: Cendikia Insani.

http. Ainiazahra. blogspot. Com /2017/02/ makalah- tentangsekolah-unggulan. html

http. Beringin komputer. Blogspot .com /2017/02 /kerja- sama- kepalasekolah-dengan-guru.htm

Irsal. 2003. Pedoman Penyelenggaraan dan Pembinaan Madrasah Diniyah. Jakarta : Depag RI Direktorat Jendral Pendidikan Keagamaan dan Pondok Pesantren.

Juliana, Anik. 2005. Pengaruh Kepemimpinan Kepala Sekolah Terhadap Mutu Pendidikan Agama Islam. Skripsi. Surabaya: IAIN Sunan Ampel.

Kunandar. 2009. Guru Profesional Implementasi Kurikulum Tingkat Satuan Pendidikan (Ktsp) Dan Sukses Dalam Sertifikasi Guru. Jakarta: Raja Wali Press.
Kemendikbud. 2004. Petunjuk Peningkatan Mutu di sekolah Dasar. Jakarta: Kemendikbud. 2007. Implementasi Kurikulum Tingkat Satuan Pendidikan Kemandirian Guru Dan Kepala Sekolah. Jakarta: PT Bumi Aksara.

Mulyasa, E., 2007. Menjadi Kepala Sekolah Profesional. Bandung: Remaja Rosda Karya.

Nurkolis. 2005. Manajemen Berbasis Sekolah. Jakarta: PT. Grasindo.

Purwanto, Ngalim. 2006. Administrasi dan Supervisi Pendidikan. Bandung: PT Remaja Rosdakarya.

Rahman. 2006. Peran Strategis Kepala Sekolah Dan Meningkatkan Mutu Pendidikan. Skripsi. Jatinangor: Alqaprit.

Shulhan, Muwahid. 2004. Administrasi Pendidikan. Jakarta: PT. Bina Ilmu.

Tim Penyusun Kamus Pusat Pembinaan dan Pengembangan Bahasa. 1989. Kamus Besar Bahasa Indonesia. Jakarta: Balai Pustaka.

Wahyosumidjo. 2001. Kepemimpinan Kepala Sekolah Tinjauan Teoritik Dan Per Permasalahannya. Jakarta: Raja Grafindo Persada. 